\title{
Nakit Akış Tablosu ile Likidite Oranları İlişkisi: Borsa İstanbul KOBİ Sanayi İşletmeleri Üzerine Bir Araştırma \\ (Relationship between Cash Flow Statement and Liquidity Ratios: A Research on Borsa İstanbul SME Industrial Enterprises)
}

\section{Feyza DEREKÖY iD a}

a İstanbul Medipol Üniversitesi, Sosyal Bilimler Meslek Yüksekokulu, İstanbul, Türkiye. fderekoy@medipol.edu.tr

\begin{tabular}{|c|c|}
\hline MAKALE BİLGİsi் & ÖZET \\
\hline $\begin{array}{l}\text { Anahtar Kelimeler: } \\
\text { Nakit Akış Tablosu }\end{array}$ & $\begin{array}{l}\text { Amaç - Çalışmada, işletmelerin likidite ölçütü olarak ifade edilen nakit akışları ile likidite oranları } \\
\text { arasında herhangi bir ilişkinin var olup olmadığını ve varsa bu ilişki düzeyinin ve yönünün } \\
\text { belirlenmesi amaçlanmıştır. }\end{array}$ \\
\hline $\begin{array}{l}\text { Nakit Akışları } \\
\text { Finansal Analiz }\end{array}$ & $\begin{array}{l}\text { Yöntem - Araştırmanın örneklemini, Borsa İstanbul KOBİ Sanayi Endeksinde faaliyet gösteren } \\
\text { işletmelerden verilerine kesintisiz olarak ulaşılabilen } 40 \text { işletme oluşturmuştur. Araştırmaya konu }\end{array}$ \\
\hline Likidite & olan işletmelere ilişkin veriler, Borsa İstanbul ve Kamu Aydınlatma Platformu resmi internet \\
\hline Likidite Oranları & $\begin{array}{l}\text { adreslerinden elde edilmiş ve analize hazır hale getirilmiştir. Araştırmanın amacına ulaşabilmesi } \\
\text { için korelasyon analizi, panel birim kök testleri, panel regresyon analizleri ve nedensellik analizleri } \\
\text { yapılmıştır. }\end{array}$ \\
\hline $\begin{array}{l}\text { Gönderilme Tarihi } 4 \text { Haziran } \\
2020\end{array}$ & $\begin{array}{l}\text { Bulgular - Analiz sonucunda, işletme faaliyetlerinden, yatırımlardan ve finansal faaliyetlerden elde } \\
\text { edilen nakit akışları ile likidite oranları arasında istatistikî olarak anlamlı bir ilişki bulunmadığı }\end{array}$ \\
\hline Revizyon Tarihi 2 Ekim 2020 & tespit edilmiştir. Ayrıca, panel nedensellik analizinin sonuçlarına göre nakit akışlarının iki \\
\hline Kabul Tarihi 14 Ekim 2020 & $\begin{array}{l}\text { gecikmeyle cari oranın bir nedeni olduğu, ancak nakit akış değişkenlerinin, nakit oranın bir nedeni } \\
\text { olmadığı belirlenmiştir. }\end{array}$ \\
\hline $\begin{array}{l}\text { Makale Kategorisi: } \\
\text { Araştırma Makalesi }\end{array}$ & $\begin{array}{l}\text { Tartışma - Araştırma sonucuna göre, likidite analizinde işletmeyle ilgili daha doğru sonuçlara } \\
\text { ulaşılması için bilanço ve nakit akış tablosu verilerinin, birlikte değerlendirilmesinin gerekliliği } \\
\text { ortaya konmuştur. }\end{array}$ \\
\hline
\end{tabular}

\begin{tabular}{|c|c|}
\hline ARTICLE INFO & ABSTRACT \\
\hline Keywords: & \multirow{2}{*}{$\begin{array}{l}\text { Purpose - In the study, it is aimed to determine whether there is a relationship between the cash } \\
\text { flows expressed as liquidity criteria of the enterprises and the liquidity ratios, and if any, the level } \\
\text { and direction of this relationship. }\end{array}$} \\
\hline Cash Flow Statement & \\
\hline$C$ & \multirow{4}{*}{$\begin{array}{l}\text { Design/methodology/approach - The sample of the research consisted of } 40 \text { companies whose data } \\
\text { can be accessed continuously, operating in the Borsa Istanbul SME Industry Index. The data related } \\
\text { to the companies subject to the research were obtained from Borsa İstanbul and Public Lighting } \\
\text { Platform official websites and made ready for analysis. Correlation analysis, panel unit root tests, } \\
\text { panel regression analyzes and causality analyzes were performed to achieve the purpose of the } \\
\text { research. }\end{array}$} \\
\hline Financial Analysis & \\
\hline Liquidity & \\
\hline Liquidity Ratios & \\
\hline $\mathrm{R}$ & \multirow{3}{*}{$\begin{array}{l}\text { Findings - As a result of the analysis, it has been determined that there is no statistically significant } \\
\text { relationship between cash flows obtained from operating activities, investments and financial } \\
\text { activities and liquidity ratios. In addition, according to the results of the panel causality analysis, it } \\
\text { has been determined that cash flows are a cause of the current rate with two delays, but cash flow } \\
\text { variables are not a cause of the cash rate. }\end{array}$} \\
\hline Revised 2 October 2020 & \\
\hline Accepted 14 October 2020 & \\
\hline Article Classification: & Discussion - As a results of the research, it has been revealed that the balance sheet and cash $\mathrm{fl}$ \\
\hline & \\
\hline
\end{tabular}




\section{GİRIŞ}

Nakit akış tablosu; işletme yöneticilerine, yatırım yapan veya yapmak isteyen yatırımcılara ve kredi kuruluşlarına, sağladığı faydadan dolayı önemli bir tablo olarak karşımıza çıkmaktadır. Nakit akışı hakkında bilgi veren nakit akış tablosu, başarısızlığa yo açan sorunların çözümüne ışık tutmaktadır. Bazı işletmelerin iflas etmelerinin ana nedenlerinden biri, finansal yükümlülüklerini yerine getirmek için yeterli nakit akışı sağlayamamalarıdır. Nakit akışı, işletmelerin sağlıklı bir finansal yapıya sahip olmalarında, sürekliliklerini korumalarında ve hedeflerine ulaşmalarında önemli rol oynamaktadır. Belirli ölçüde nakit akışı yaratabilen işletmeler faaliyetlerini sürdürebilecek, borçlarını ve diğer yükümlülüklerini karşılayabileceklerdir.

Çalışmanın amacı, nakit akış tablosunda hesaplanan ve likidite ölçütü olarak ifade edilen nakit akışları ile kısa vadeli yükümlülükleri karşılayabilme gücü ve "nakit" gibi cari varlıkların yeterliliğini ölçen likidite oranları arasındaki ilişki düzeyini belirlemektir. Bu kapsamda, çalışmada öncelikle nakit akış tablosu ve nakit akışları ile likidite ve likidite oranları kavramsal olarak ele alınmıştır. Daha sonra Borsa İstanbul KOBİ Sanayi Endeksinde yer alan ve verilerine ulaşılan 40 işletmenin, 2014- 2018 yıllarına ait finansal tabloları kullanılarak, nakit akışları ve likidite oranları hesaplanmıştır. Araştırmaya konu olan, nakit akışları ve likidite oranları arasındaki ilişki, panel veri analizi yöntemi ile test edilmiş ve elde edilen bulgular değerlendirilmiştir.

\section{LITTERATÜR İNCELEMESİ}

Nakit akış tablosu, belli bir dönemde işletmenin faaliyetleri bazında nakit akışlarını raporlamaktadır. Literatürde nakit akışları ile işletme performansı ilişkisini belirlemeye yönelik birçok çalışma söz konusudur. Ancak, işletmenin likidite durumunu gösteren nakit akış tablosu ile likidite oranları arasındaki ilişkiyi ele alan çalışma sayısı sınırlı sayıdadır.

Uygurtürk ve Vargün (2018), Borsa İstanbul' da işlem gören taşıt araçları sanayii işletmeleri üzerine yapmış oldukları çalışmalarında, nakit akış unsurlarının işletme karlılığı üzerindeki etkisi belirlenmeyi amaçlamışlardır. Çalışma kapsamındaki işletmelerin finansal verilerinde çoklu regresyon analizleri gerçekleştirilmiş ve elde edilen sonuçlar işletme bazında değerlendirilmiştir.

Nakit akışları ile işletme performansı arasındaki ilişkiyi ölçen bir başka çalışma, Cyril vd. (2016) tarafından Nijerya Borsası'nda işlem gören yiyecek ve içecek sektöründeki işletmeler kapsamında gerçekleştirilmiştir. Çalışmanın sonucunda, işletmelerin işletme faaliyetleri ve finansman faaliyetleri sonucunda elde edilen nakit akışları ile performansları arasında pozitif anlamlı bir ilişki bulunduğu, ancak yatırım faaliyetlerinden elde edilen nakit akışları ile firma performansı arasında negatif bir ilişki olduğu ortaya konmuştur. Nijerya yiyecek ve içecek sektöründeki işletmeler üzerinde bir başka çalışma Yero ve Usman (2013) tarafından gerçekleştirilmiştir. Söz konusu çalışmada, araştırma kapsamındaki işletmelerin serbest nakit akışları ile karlılıkları arasındaki ilişki incelenmiştir. Araştırma sonucu, işletmelerin serbest nakit akışları ile aktif karlılıkları arasında negatif bir ilişki olduğunu göstermiştir.

Chikashi'nin (2013), Tokya Borsası'nda elektrikli cihaz sektöründeki işletmelerin 2009 ile 2011 yılları arasındaki finansal verilerinde, panel veri analiz yöntemi ile gerçekleştirdiği araştırma sonuçlarına göre nakit akışları ile firma performansı arasında negatif yönde bir ilişki olduğunu saptamıştır. Benzer şekilde, Zhou vd. (2012) tarafından yapılan çalışmada, Çin borsasına kayıtlı emlak şirketlerinin 2006- 2011 yılları arasındaki verileri regresyon analiz yöntemiyle analiz edilmiştir. Çalışma sonucunda işletmenin nakit akışları ile performansı arasında negatif bir ilişki olduğu ortaya konmuştur.

Diğer bir taraftan, Brush vd. (2000), serbest nakit akım teorisini incelemek üzere gerçekleştirdikleri çalışmada, 1988 ile 1995 yılları arasındaki mali verileri ele almışlardır. Araştırma bulgularına göre, firma performansı ile nakit akışları arasında pozitif anlamlı bir ilişki bulunmaktadır. Ayrıca, Ashitiani (2005), Tahran Borsasında muhasebe oranları, nakit akışları ve hisse senedi getirisi arasındaki ilişkiyi inceleyen çalışmasında, 650 işletmenin 1998 ile 2004 yılları arasındaki ilişkiyi Pearson korelasyon ve doğrusal regresyon analizi yöntemini kullanarak analiz etmiştir. Araştırma sonucuna göre, faaliyet karı, net kar, işletme faaliyetlerine ilişkin nakit akışları, yatıım faaliyetlerine ilişkin nakit akışları ile hisse senedi getirisi arasında anlamlı bir ilişki söz konusudur, ancak finansal faaliyetlere ilişkin nakit akışları ile hisse senedi getirisi arasında anlamlı bir ilişki bulunmaktadır. Bunun yanı sıra, Watson (2005), nakit akışları ile firma performansı ve hisse senedi getirisi 
arasındaki ilişkiyi basit ve çoklu regresyon yöntemini kullanarak analiz etmiştir. Çalışma bulgularına göre, nakit akışları ile performans arasında negatif bir ilişki söz konusudur.

Nakit akışları ve likidite ilişkisini ele alan sınırlı sayıdaki çalışmalardan biri imalat işletmeleri üzerinde gerçekleştirilmiştir. Bu çalışmada, Sontakke ve Mallya (2019) araştırma kapsamındaki işletmelerin likidite oranları ile faaliyetlerinden elde edilen nakit akışları arasındaki ilişkiyi analiz etmişler ve sonuç olarak likidite oranları ile faaliyetlerden elde edilen nakit akışları arasında negatif bir ilişki olduğunu belirlemişlerdir. Noor vd. (2012) ise, işletmelerin farklı finansal getiri değişkenleri (kazanç, faaliyetlerden elde edilen işletme sermayesi, faaliyetlerden elde edilen nakit akışları) ile likiditeleri arasındaki ilişkiyi ölçen çalışmalarında, faaliyetlerden elde edilen nakit akışları ile cari oran arasında pozitif bir ilişki olduğunu tespit etmişlerdir. Benzer bir çalışma ise Okoye vd. (2016) tarafından, Nijerya Borsasına kayıtlı ticari bankalar üzerinde gerçekleştirilmiştir. Çalışmada, nakit akış tablosu ile likidite oranı arasındaki ilişki regresyon analizi ile incelenmiş ve çalışmanın sonucunda, nakit akım tablosunun çalışma kapsamındaki bankaların likiditesi üzerinde pozitif ve anlamlı bir etkisi olduğu tespit edilmiştir.

\section{KAVRAMSAL ÇERÇEVE}

\subsection{Nakit Akış Tablosu ve Nakit Akışları}

Nakit akış tablosu, işletme ile ilgili taraflara, işletmenin belli bir süre içinde elde ettiği nakdi ve bu nakdi nerelerde kullandığını gösteren bir finansal tablodur. İşletme ilgili tarafların ekonomik kararlar alabilmeleri için, işletmenin nakit yaratma gücünü, zamanlamasını ve hassasiyetini değerlendirmeleri gereklidir. Bu nedenle, söz konusu değerlendirmeler için kullanılan finansal tablolardan biri de nakit akış tablosudur (Özerhan ve Yanık, 2012: 65). Tahakkuk esasına göre belirlenen finansal tablo bilgilerini nakit esasına göre ilişkili taraflara sunmak için kullanılan nakit akış tablosu, nakit giriş ve çıkışlarını toplam ve faaliyet bazında belirler (Karapınar ve Eflatun, 2017: 39).

Nakit giriş ve çıkışlarının sunulduğu nakit akış tablosu, işletmelerin finansal hedeflerine ulaşmadaki güçleri ile birlikte likidite ve karlılıklarını belirlemelerine, varlıkların verimliliği ve finansal yönetim açısından kendilerini değerlendirmelerine yardımcı olmaktadır. Nakit akış tablosu ayrıca, temel finansal tabloların ortak özelliklerinden biri olarak işletmelerin performansları hakkında tarihi bilgileri sunmaktadır (Omag, 2016: 116). Diğer bir ifadeyle, nakit akış tablosu, diğer finansal tablolarla kullanıldığında işletme ilgili taraflara, işletmenin aktiflerinin net değerindeki değişimi, finansal yapısını ve bunun yanında nakit akışlarını etkileyebilme becerisini değerlendirmeleri için gerekli bilgiyi sağlamaktadır (Cavlak vd., 2017: 236).

Bu bağlamda nakit akış tablosunun, işletme ile ilgili taraflara sağladığı faydaları aşağıdaki gibi özetlemek mümkündür (Williams vd., 2008: 572);

- İşletmenin gelecek dönemlerde pozitif nakit akışı yaratma becerisini ölçmek,

- İşletmenin yükümlülüklerini yerine getirme ve kar payı dağıtma becerisini değerlendirmek,

- İşletmenin ek finansman ihtiyacını belirlemek,

- Net kar ve faaliyetlerinden sağlanan nakit akışları arasındaki farklılıkların sebeplerini değerlendirmek,

- Dönem içinde yatırım ve finansman faaliyetlerinin nakit ve nakit dışı etkilerini göstermek,

- Nakit ve nakit benzeri varlıkların dönem başı ve dönem sonu tutarlarındaki farklılıkların nedenlerini değerlendirmek.

İşletmenin nasıl nakit yarattığı ve nasıl kullandığını ortaya koyma amacıyla düzenlenen, nakit akış tablosu, nakdin nereden geldiğini bilmek ve gelecekte nakidin buralardan temin edilip edilemeyeceğini tahmin etmek için önemlidir. Nakdin nerede kullanıldığını bilmek ise, işletmenin gelecekte ortaya çıkabilecek nakit ihtiyacının belirlenmesi açısından önemlidir (Günceme ve Arsoy, 2006: 67). Nakit ve nakit benzeri varlıkların işletmeye giriş ve çıkışları olarak tanımlanan nakit akışları, işletme için likidite ölçütü olup kurumsal performansa katkıda bulunan bir faktördür (Frank ve James, 2014: 78). Bunun yanında, muhasebe bilgi kullanıcıları esasen işletmenin finansal tablolarındaki nakit varlıkları ile ilgilenirler (Ogbeide ve Akanji, 2017: 149). 
Nakit akış tablosu, işletmenin nakit akışlarını, faaliyetlerden elde edilen nakit akışları, yatırımlardan elde edilen nakit akışları ve finansal faaliyetlerden elde edilen nakit akışları olarak üç gruba ayırmaktadır (Subatnieks, 2005: 164). İşletme faaliyetlerine ilişkin nakit akışları, varlık edinme, borç ödeme ve nakit temettü ödemesi için gerekli olan ve temel gelir getirici faaliyetlerden elde edilen nakit akışlarıdır (Gup ve diğerleri, 1993: 74). İşletme faaliyetlerinden elde edilen nakit akışları, işletmenin ana faaliyetleri olan üretim, satış ve kiraya verme gibi faaliyetlerle ilgilidir ve burada ortaya çıkan olumlu bir gelişme ise, işletmenin performansının pozitif bir göstergedir (Yılmaz ve İçten, 2018: 74). Yatırım faaliyetlerine ilişkin nakit akışları, maddi duran varlık satışından kaynaklanan nakit girişlerinden ve maddi duran varlık alımlarından kaynaklanan nakit çıkışlarından oluşmaktadır (Petro ve Gean, 2014: 319). Finansal faaliyetlerine ilişkin nakit akışları ise, işletmeye sermaye sağlayanların işletmenin gelecekteki nakit akışlarından talep edecekleri kısmı ifade etmekte olup (Gökçen, 2011: 144), kredi verenlerden elde edilen nakitler, borçlanmaya ilişkin geri ödeme tutarları, işletmeye sermaye sağlayanların nakit sermaye girişleri ve nakit olarak alınan kar payları gibi işlemlere ilişkin nakit hareketlerinden oluşmaktadır (Uyguntürk ve Vargün, 2018: 711). Nakit akış tablosunun söz konusu faaliyet türlerine göre düzenlenme esasları "TMS 7 Nakit Akış Tablosu” Standardı ile belirlenmiştir.

Standardın amacı, dönem boyunca işletme, yatırım ve finansman faaliyetlerinden kaynaklanan nakit akışlarını sınıflandıran bir nakit akış tablosu aracılı̆̆ ile işletmenin nakit ve nakit benzerlerindeki geçmiş değişiklikler hakkında bilgi sağlamaktır (TMS 7). Standarda göre nakit akışları, brüt yöntem ve net yöntem olmak üzere iki yönteme göre raporlanabilir. Brüt nakit girişleri ve brüt nakit çıkışlarına ait ana grupların belirtildiği brüt (dolaysız) yöntem, nakit akışlarının tahmin edilmesi açısından daha ayrıntılı bilgiler sunulmaktadır. Satışlar ve satışların maliyetine ilişkin verilerden, stoklar ve alacaklar gibi nakit etkisi olan tüm hesap kalemlerine ilişkin ayrıntılı bir incelemeyle oluşturulmaktadır. Net (dolaylı) yöntem ise, gelir tablosundaki net kar ya da zararın esas alındığı ve net kar ya da zararın; gayri nakdi işlemler, gerçekleşmiş veya gerçekleşecek işlemlerle ilgili nakit giriş veya çıkış tahakkukları ve ertelemeleri ve yatırım veya finansman faaliyetleri ile ilgili nakit akışlarına ilişkin gelir veya gider kalemlerinin etkilerine göre düzeltildiği yöntemdir (Karğın ve Aktaş, 2011: 4- 5).

\subsection{Likidite ve Likidite Oranlarn}

Varlıkları nakde çevirme veya nakit elde etme beceri olarak tanımlanan likidite, bir işletmenin istenmeyen zararlara maruz kalmadan, kısa vadeli yükümlülüklerini karşılama yeteneğine sahip olup olmadığını ölçen önemli bir finansal göstergedir (Billah vd., 2015: 3). İşletmenin kısa vadeli yükümlülüklerini yerine getirme gücü, likidite analizi ile araştırılır. Kısa vadeli yükümlülüklerin yerine getirmesinde güçlüğe düşülmemesi için kısa vadeli yabancı kaynaklar ile dönen varlıkların belirli bir dengede tutması gerekmektedir. Bu dengenin varlığını ortaya çıkarmak için likidite analizi de yapılmaktadır. Bu nedenle, likidite analizinde dönen varlıklar ve kısa vadeli yükümlülükler arasında anlamlı ilişkiler kuran likidite oranlarından yararlanılır (Karapınar ve Zaif, 2013: 207). Likidite oranları, bir işletmenin kısa vadeli borçlarını dönen varlıklarının tamamı veya bir kısmı ile karşılayabilme yeteneğinin ölçülmesini sağlar (Günay, 2014: 47). Likiditenin temel geleneksel göstergesi olan likidite oranları, cari oran ve asit-test oranıdır (Bolek ve Grosicki, 2012: 235- 236).

Cari oran, işletmenin toplam likiditesini ölçen oran olup, işletmenin cari varlıklarının (dönen varlılar), cari kaynaklarını (kısa vadeli yabancı kaynaklar) kaç defa kapsadığını yani kaç katı olduğunu göstermektedir. Cari oran aşağıdaki gibi hesaplanmaktadır (Okka, 2006: 66);

$$
\text { Cari Oran }=\frac{\text { Dönen Varlıklar }}{\text { Kısa Vadeli Yabancı Kaynaklar }}
$$

Cari oran, kısa vadeli yabancı kaynakların ödenmesinde herhangi bir güçlük olup olmayacağı konusunda fikir vermektedir. Kısa vadeli yabancı kaynaklarını zamanında karşılayamaması işletmeyi iflasa kadar götürebilecek önemli riskleri içermektedir (Tokaç, 2005: 117- 118). Ancak, cari varlıkların bazılarının nakde çevrilmeye hazır olmaması, cari oranda değişiklik yapılması ihtiyacını ortaya çıkarmıştır. Daha az likit olan varlıklar olan, stoklar ve peşin ödenmiş giderlerin, cari varlıklardan çıarılması ve kısa vadeli yabancı kaynaklarla karşılaştırılması ile asit-test oranı elde edilmiştir. Stokların potansiyel bir nakit girişi olabilmesi için satılması gerekmektedir. Oysa, ticari alacaklar, işletmelerin daha önce satılan mal ve hizmetlerin ödenmesine ilişkin müşterilerinden talep edebilecekleri haklarını ifade eder. Peşin ödenmiş giderlerin ise 
işletmeye gelecekte nakit girişi sağlaması mümkün değildir. Söz konusu düzenlemelerin sonucunda, asit-test oranı aşağıdaki gibi hesaplanmaktadır (Robinson vd., 2004: 237);

$$
\text { Asit }- \text { test Oranı }=\frac{\text { Hazır Değerler }+ \text { Menkul Kıymetler }+ \text { Ticari Alacaklar }}{\text { Kısa Vadeli Yabancı Kaynaklar }}
$$

Asit-test oranı, cari oranı tamamlayan ve stoklar gibi nispeten nakde dönüşümü gecikecek olan varlıkların çıkarılması ile cari oranı daha anlamlı bir hale getiren orandır. Ancak, bazı yazarlar, alacakların da stoklar gibi istendiğinde kullanılabilir bir ödeme aracı olmadığını ifade etmektedirler (Ceylan ve Korkmaz, 2008: 49). Bu nedenle, asit-test oranında yer alan alacakların tahsil belirsizliğini ortadan kaldıran nakit oran geliştirilmiştir. Nakit oran aşağıdaki gibi hesaplanmaktadır (Lazol, 2008: 72);

$$
\text { Nakit Oran }=\frac{\text { Hazır Değerler }+ \text { Menkul Kıymetler }}{\text { Kısa Vadeli Yabancı Kaynaklar }}
$$

Nakit Oranı, asit-test oranından daha katı bir ölçü olarak kabul edilebilir. Dolayısıyla söz konusu oran, işletmenin satışlarının durması ve alacaklarını tahsil edememesi durumunda, kısa vadeli yükümlülüklerini karşılama kabiliyetini göstermektedir (Akgüç, 1998: 30).

\section{UYGULAMA}

\subsection{Araştırmanın Amacı}

İşletmenin nakit durumunu göstermek amacıyla düzenlenen nakit akış tablosu, gelecek dönemlerde işletmenin nakit yaratma becerisini ortaya koymasının yanı sıra borçlarını ödeyebilme gücü hakkında da bilgi vermektedir (Karapınar ve Eflatun, 2018: 39; Williams, 2008: 572 ve Wolk ve Tearney, 1997: 384). Bu durumda, nakit akışları yeterli düzeyde olan bir işletmenin, kısa vadeli yükümlülüklerini karşılayabilme gücünü ve nakit gibi cari varlıklarının yeterliliğini ölçen likidite oranlarının da yüksek değerlerde olmasını beklemek olasidir.

Buna karşın, nakit akışları yüksek olan bir işletme, nakit akışlarının yaratacağı kaynak ile faaliyet giderlerini ve vadesi gelen borçlarını ödeyebileceğinden, daha az nakit ve nakit benzeri varlık bulundurabilecektir (Kim vd., 2019: 348). Bu bağlamda, araştırmanın amacı, nakit akış tablosunda hesaplanan nakit akışları ile likidite oranları arasındaki ilişki düzeyini belirlemektir.

\subsection{Araştırmanın Veri Seti ve Yöntemi}

Araştırma verileri elde edilirken kolayda örnekleme yöntemi kullanılmıştır. Araştırmanın örneklemini, 20142018 yılları arasında Borsa İstanbul KOBİ Sanayi Endeksi'nde yer alan 41 işletmeden, verilerinin tamamına ulaşılabilen 40 sanayi işletmesi oluşturmaktadır. KOBİlerin ülke ekonomilerindeki oransal büyüklügüüün yanı sıra, toplam istihdam, katma değer, yatırım, vergi, ihracat ve krediler içindeki payları da önemli boyutlara ulaşmıştır. Ülkemizde de işletmelerin \%99'dan fazlası KOBI'lerden oluşmakta ve istihdamında \%70' den fazlasını da KOBİler sağlamaktadır (Özdemir vd.,2007: 174- 175; Bayülken ve Kütükoğlu, 2012: 15- 16).

Araştırmanın, Borsa İstanbul KOBİ Sanayi Endeksi'nde yer alan ve verilerine ulaşılabilen 40 sanayi işletmesi üzerinde gerçekleştirilmiş olması, sonuçlarının genelleştirilmesi açısından araştırmanın kısıtını oluşturmaktadır. Araştırma kapsamındaki işletmelerin, 2014- 2018 yılları arasındaki nakit akışlarının, likitide oranları üzerindeki etkilerini belirlemek amacıyla, işletmelere ait nakit akışları ve likidite oranları, Borsa İstanbul'un resmi internet sitesinden ve Kamuyu Aydınlatma Platformu'ndan (KAP) 29 Kasım 2019 tarihinde elde edilen finansal tablolar kullanılarak hesaplanmıştır.

İşletmelerin nedensel durumunda olan değişkenleri, nakit akış tablosunda hesaplanan "işletme faaliyetlerinden nakit akışları" (INA), "yatırımlardan nakit akışları" (YNA) ve "finansal faaliyetlerden nakit akışları" (FNA)' dır. Sonuç durumunda olan değişkenleri ise, likiditenin ölçümünde geleneksel olarak kullanılan "cari oran" (CR) ile işletmelerin nakit varlıklarının yeterliliğini ölçen "nakit oran" (NR)' dır. Araştırmanın verileri, panel veri konumunda olup, neden durumunda olan değişkenlerin, sonuç durumunda olan değişkenlere etkisini test etmek için aşağıdaki iki model oluşturulmuştur. Oluşturulan bu modeller panel veri analizi ile tahmin edilmiştir. 


$$
\begin{aligned}
& C R_{i t}=C+\beta_{i t}(\dot{\mathrm{I}} N A)+\beta_{i t}(Y N A)+\beta_{i t}(F N A)+U_{i t} \\
& N R_{i t}=C+\beta_{i t}(\dot{I} N A)+\beta_{i t}(Y N A)+\beta_{i t}(F N A)+U_{i t}
\end{aligned}
$$

Panel veriler, çok sayıdaki kesite ait zaman serileri veya zaman boyutuna sahip kesit veriler olarak tanımlanmaktadır. Zaman serisi, bir değişkenin veya değişkenlerin zaman içindeki değerlerinden, kesit verilerindeki değerler ise, değişkenlerin veya değişkenlerin zamanla elde ettiği değerlerin tek bir noktasındaki çeşitli örneklemlerden oluşmaktadır. Panel veri analizi, zaman içinde analiz edilen değişkenlerin aynı kesit birimleri içinde gözlemlenmesini sağlamaktadır. Bu bağlamda, gözlemlenen ekonomik birimlerin zaman serileri ve yatay kesit gözlemleri bir arada kullanılarak panel veri setini oluşturmaktadır (Grene, 2003: 283285).

\subsection{Araştırmanın Bulguları}

Çalışmanın bu bölümünde, araştırmanın amacına ulaşabilmesi için yapılan panel regresyon analizleri, panel birim kök testleri, panel eş bütünleşme analizleri ve panel nedensellik analizleri sonucu ulaşılan bulgulara ve değerlendirmelere yer verilmiştir.

\subsubsection{Hausman Testi}

Panel veri modellerinin tahmininde diğer bir ifadeyle panel regresyon tahmininde sabit etki ve rassal etki (tesadüfi etki) olarak iki yaklaşım bulunmaktadır. Sabit etki yaklaşımı, modelde yer alan her birimdeki farklılıkların, sabit terimlerdeki farklılıklarla tahmin edilebileceğini varsaymaktadır. Rassal etki yaklaşımı ise, birimler arasındaki sabit katsayıların farklılaşmadığını varsaymaktadır (Grene, 2003: 301). Sabit etki ve rassal etki yaklaşımlarından hangisinin panel regresyon modelleri için uygun olduğunun tespit edilmesi gerekmektedir. Araştırmada uygun model seçiminde, literatürde en çok kullanılan yöntem olan Hausman testinden yararlanılmıştır. Bu testte, rassal etki yaklaşımının, sabit etki yaklaşımından daha etkin olduğunu ileri süren $\mathrm{H}_{0}$ hipotezi ile sabit etki yaklaşımının, rassal etki yaklaşımından daha etkin olduğunu ileri süren bir alternatif hipotez söz konusudur. Böylece Hausman test istatistiğinin hipotezleri aşağıdaki gibi kurulmaktadır.

$\mathrm{H}_{0}$ : Rassal etki daha uygundur.

$\mathrm{H}_{1}$ : Sabit etki daha uygundur.

Araştırmada öncelikle panel veri regresyon tahminlerinde, her bir model için sabit ya da rassal etkiye dayalı modellerden hangisinin uygun olacağı, Hausman testi ile belirlenmiştir. Hausman Testi sonuçları Tablo 1'de verilmiştir:

Tablo 1. Hausman Test İstatistikleri Sonuçları

\begin{tabular}{|l|c|c|}
\hline & Model 1 & Model 2 \\
\hline Hausman Testi & 4.436517 & 27.843739 \\
\hline P-Değeri & 0.2180 & 0.0000 \\
\hline
\end{tabular}

Tablo 1'de verilen test sonuçlarına göre Cross-section random değerine yönelik olasılık değeri model 1 için 0,05' den büyük olduğundan sıfır hipotezi kabul edilmiş ve söz konusu model için panel regresyonuna ilişkin uygun modelin rassal etkiye dayalı olması gerektiği belirlenmiştir. Bağımlı değişkenin, nakit oran (NR) olduğu regresyon modelinde (model 2), tahmin yönteminin belirlenmesi için yapılan Hausman Testine göre Cross-section random değerine yönelik olasılık değeri 0,05' den küçük olduğundan, sıfır hipotezi reddedilmiş ve model 2 için panel regresyonuna ilişkin uygun modelin, sabit etkiye dayalı olması gerektiği tespit edilmiştir. 


\subsubsection{Panel Regresyon Analizi}

Model 1 için rassal etkili panel veri regresyon tahmin sonuçları Tablo 2'de sunulmuştur:

Tablo 2. Model 1 için Rassal Etkiye Göre Panel Veri Regresyon Sonuçları

\begin{tabular}{|c|c|c|c|c|}
\hline Değişkenler & Katsayılar & Standart Hata & t-istatistiği & Olasılık (P değeri) \\
\hline $\mathrm{C}$ & 2.574717 & 0.408330 & 6.305476 & 0.0000 \\
\hline İNA & 1.62E-09 & 3.69E-08 & 0.043757 & 0.9651 \\
\hline YNA & 1.20E-08 & $3.45 \mathrm{E}-08$ & 0.346943 & 0.7290 \\
\hline FNA & $-2.22 \mathrm{E}-09$ & $3.48 \mathrm{E}-08$ & -0.063794 & 0.9492 \\
\hline $\mathrm{R}^{2}$ & \multicolumn{4}{|c|}{0.001619} \\
\hline Düzeltilmiş $\mathrm{R}^{2}$ & \multicolumn{4}{|c|}{-0.013662} \\
\hline $\mathrm{F}$ istatistiği & \multicolumn{4}{|c|}{0.105975} \\
\hline Olasılık (F istatistiği) & \multicolumn{4}{|c|}{0.956517} \\
\hline Durbin-Watson istatistiği & \multicolumn{4}{|c|}{1.792128} \\
\hline Gözlem Sayısı & \multicolumn{4}{|c|}{ 2014-2018 yılları arası, 40 işletme 200 gözlem } \\
\hline Standart Regresyon Hatas 1 & \multicolumn{4}{|c|}{3.008011} \\
\hline
\end{tabular}

Tablo 2' de elde edilen sonuçlara göre bağımlı değişkenin cari oran (CR) olduğu panel regresyon denkleminde, işletme faaliyetlerinden nakit akışları (INA), yatırımlardan nakit akışları (YNA) ve finansal faaliyetlerden nakit akışları (FNA) değişkenlerinin, istatistiksel açıdan anlamlı olmadığı ve cari oran (CR) değişkeni üzerinde önemli bir etkiye sahip olmadığı belirlenmiştir. Tablo 3'te ise, Model 2 için sabit etkili panel veri regresyon tahmin sonuçları sunulmuştur:

Tablo 3. Model 2 için Sabit Etkiye Göre Panel Veri Regresyon Sonuçları

\begin{tabular}{|c|c|c|c|c|}
\hline Değişkenler & Katsayılar & Standart Hata & $\mathrm{t}$-istatistiği & Olasılık (P değeri) \\
\hline$C$ & 0.578591 & 0.095139 & 6.081528 & 0.0000 \\
\hline İNA & $2.11 \mathrm{E}-08$ & 1.61E-08 & 1.312155 & 0.1914 \\
\hline YNA & $2.96 \mathrm{E}-08$ & $1.52 \mathrm{E}-08$ & 1.927822 & 0.0560 \\
\hline FNA & $2.89 \mathrm{E}-08$ & $1.50 \mathrm{E}-08$ & 1.925762 & 0.0559 \\
\hline $\mathrm{R}^{2}$ & \\
\hline Düzeltilmiş $\mathrm{R}^{2}$ & \multicolumn{4}{|c|}{0.301824} \\
\hline Log Olasilığ & \multicolumn{4}{|c|}{-306.5823} \\
\hline F istatistiğ $i$ & \multicolumn{4}{|c|}{3.048296} \\
\hline Olasıllk (F istatistiği) & \multicolumn{4}{|c|}{0.000000} \\
\hline Akaike Bilgi Kriteri & \multirow{2}{*}{\multicolumn{4}{|c|}{3.495823}} \\
\hline Shwarz Kriteri & & & & \\
\hline
\end{tabular}




\begin{tabular}{|l|c|}
\hline Hannan-Quinn Kriteri & 4.204961 \\
\cline { 1 - 2 } Durbin-Watson istatistiği & 3.782800 \\
\cline { 1 - 2 } Gözlem Sayısı & 2.077055 \\
\cline { 1 - 2 } Standart Regresyon Hatası & 2014-2018 yılları arası, 40 işletme 200 gözlem \\
& 1.264920 \\
\hline
\end{tabular}

Tablo 3'te elde edilen sonuçlara göre bağımlı değişkenin nakit oran (NR) olduğu panel regresyon denkleminde, işletme faaliyetlerinden nakit akışları (INA), yatırımlardan nakit akışları (YNA) ve finansal faaliyetlerden nakit akışları (FNA) değişkenlerinin, istatistiksel açıdan anlamlı olmadığı ve nakit oran (NR) değişkeni üzerinde önemli bir etkiye sahip olmadığı belirlenmiştir.

\subsubsection{Panel Birim Kök Testi}

Ekonometrik zaman serilerinde ekonometrik modelin anlamlı sonuçlar vermesi için ilk olarak zaman serisinin durağanlığının test edilmesi gerekir. Durağanlık durumunda serilerin varyansında ve ortalamasında simetrik anlamda bir değişme olmaması ve serinin tüm gözlem değerlerinin kovaryanslarının sabit bir değere eşit olmasıdır (Göktaş vd, 2019: 159). Eğer serinin varyansı ve ortalaması, zamandan bağımsız ve kovaryansıda zamanlar arası farka bağlı olarak gerçekleşiyor ise serinin durağan olduğu söylenir. Durağan seriler, birim kök içermeyen serilerdir (Sarıkovanlık vd., 2019: 185). Durağan olmayan zaman serileri ile tahmin edilen modelde parametre değerleri ve istatistikleri yanlış hesaplanmakta ve ekonometrik anlamda tutarsız sonuçlar hesaplanmaktadır (Göktaş vd, 2019: 159). Araştırma değişkenleri için kurulan hipotezler aşağıdaki gibidir;

$\mathrm{H}_{0}$ : Seride birim kök vardır. Seri durağan değildir $\left(\rho_{i}=\rho=1\right)$.

$\mathrm{H}_{1}$ : Seride birim kök yoktur. Seri durağandır $\left(\rho_{i}=\rho<1\right)$.

Panel verilerin zaman içerisinde durağan olup olmadığının belirlenmesinde gerek dengeli panel uygulanan panel veri, gerek dengeli panel olması aranmayan serilere yönelik kullanılan panel birim kök testleri birlikte ele alınmıştır. Panel birim kök testleri, her değişken için ayrı ayrı gerçekleştirilmiştir. Panel birim kök testleri içerisinde ana referans, Levin, Lin \& Chu t testinin sonuçlarıdır (Sarıkovanlık vd., 2019: 193). Araştırmada kullanılan her bir değişkenin durağanlığının analizinde kullanılan birim kök test sonuçları, Tablo $4^{\prime}$ te verilmiştir:

Tablo 4. Panel Birim Kök Testleri

\begin{tabular}{|c|c|c|c|c|c|c|c|c|c|c|}
\hline & \multicolumn{2}{|c|}{ CR } & \multicolumn{2}{|c|}{ NR } & \multicolumn{2}{|c|}{ İNA } & \multicolumn{2}{|c|}{ YNA } & \multicolumn{2}{|c|}{ FNA } \\
\hline Yöntem & İstatistik & Olasilık & İstatistik & Olasilik & İstatistik & Olasılık & İstatistik & Olasilik & İstatistik & Olasilık \\
\hline Levin, Lin \& Chu $\mathrm{t}$ & -55.086 & 0.0000 & -1381.35 & 0.0000 & -8.16438 & 0.0000 & -36.3877 & 0.0000 & -12.0943 & 0.0000 \\
\hline $\begin{array}{l}\text { PP- Fisher Chi- } \\
\text { square }\end{array}$ & 138.664 & 0.0001 & 152.072 & 0.0000 & 112.553 & 0.0096 & 128.728 & 0.0005 & $5 \quad 94.8408$ & 0.0407 \\
\hline
\end{tabular}

Tablo 4'ten elde edilen sonuçlar, birim kök testlerinde araştırma değişkenlerinin gerek Levin, Lin \& Chu t testi gerek PP- Fisher Chi-square testlerine göre, birim köke sahip olmadığı belirlenmiş ve düzeyde durağan olduğuna karar verilmiştir. Sonuç olarak araştırmada kullanılan likitide oranları ve nakit akışları serilerinde birim kök olmadığı yani durağan oldukları kabul edilmiştir. 


\subsubsection{Panel Eşbütünleşme Testi}

Panel veriye yönelik zaman serilerinde, uzun dönemli ilişkiyi incelemek amacıyla geliştirilen yaklaşım, zaman serilerinde olduğu gibi panel veri analizinde de eş bütünleme yaklaşımı olarak adlandırılmaktadır (Guriş 2015: 269). Ekonometrik zaman serilerinin birim kök içerdiği durumlarda, bu serilerin doğrusal kombinasyonları durağan olabilmekte ve seriler uzun vadede ilişkilendirilebilmektedir (Tatoğlu, 2012: 233). Ancak araştırmada ele alınan likitide oranları ve nakit akış serilerinin, Levin, Lin \& Chu t testine göre, birim köke sahip olmadığı belirlenmiş ve düzeyde durağan olduğuna karar verilmiştir. Dolayısıyla araştırmada, düzeyde durağan serilere eşbütünleşme testi yapmaya gerek olmadan, nedensellik analizine karar verilmiştir.

\subsubsection{Panel Nedensellik Testi}

Zaman serileri analizinde değişkenler arasındaki nedensel ilişkiler, nedensellik analizi ile test edilmektedir. Nedensellik analizinde iki değişken arasında ilişkinin yönü, Granger nedensellik temelli nedensellik analizleri ile araştırılmaktadır. Zaman serilerinde olduğu gibi panel veri modellerinde de nedensellik ilişkisinin araştırılması Granger nedensellik mantığına dayanmaktadır. Granger nedensellik analizinde, mevcut bir Y değişkeninin değeri, diğer $X$ değişkeninin mevcut değerinden ziyade geçmiş devre değerlerinden daha iyi tahmin ediliyorsa, $X$ değişkeninden $Y$ değişkenine doğru nedensellik ilişkisinin varlığından bahsedilebilir (Güriş, 2015: 295). Panel nedensellik için kullanılacak denklem aşağıdaki gibi ifade edilebilir.

$$
y_{i t}=\alpha_{i}+\sum_{k=1}^{k} \gamma^{(k)} y_{i t-k}+\sum_{k=1}^{k} \beta^{(k)} x_{i t-k}+\varepsilon_{i t}
$$

Denklem 3' de $\alpha_{\mathrm{i}}$ işletmelere özgü etkileri, $\gamma^{(k)}$ ve $\beta^{(k)}$ bütün işletmeler için aynı olduğu varsayılmaktadır.

Araştırmada, işletmelerin nakit akışlarının, likitide oranları üzerindeki etkileri belirlenmek istendiğinden, çalışmanın iki bağımlı değişkeni vardır. Bu değişkenler işletmelere yönelik sonuç durumunda olan değişkenler olan cari oran (CR) ve nakit oran (NR)'dır. Bağımsız (nedensel) değişkenler, işletmelerin elde ettikleri nakit akışları olduğundan tek yönlü nedensellikler incelenecektir. Araştırmada yöntem olarak VEC Granger Causality/Block Exogeneity Wald Testi kullanılmış olup, cari oran (CR) değişkenine yönelik nedensellik testi sonuçları Tablo 5'te sunulmuştur:

Tablo 5. Cari Orana Yönelik Panel Nedensellik Testi Sonuçları

\begin{tabular}{|c|c|c|c|c|}
\hline $\begin{array}{c}\text { Bağımlı } \\
\text { Değişken }\end{array}$ & $\begin{array}{c}\text { Dişlanan } \\
\text { Değişkenler }\end{array}$ & $\begin{array}{c}\text { Ki-kare } \\
\text { İstatistiği }\end{array}$ & $\begin{array}{c}\text { Serbestlik } \\
\text { Derecesi }\end{array}$ & P değeri \\
\hline \multirow{2}{*}{$\begin{array}{c}\text { Cari Oran } \\
(\mathrm{CR})\end{array}$} & İNA & 14.21904 & 2 & 0.0008 \\
\cline { 2 - 5 } & YNA & 18.41718 & 2 & 0.0001 \\
\cline { 2 - 5 } & FNA & 30.76010 & 2 & 0.0000 \\
\cline { 2 - 5 } & All & 35.21226 & 6 & 0.0000 \\
\hline
\end{tabular}

Tablo 5'ten elde edilen sonuçlara göre, sonuç (bağımlı) durumunda olan değişken işletmelerin cari oranı (CR) olduğunda, iki gecikmeyle nedensel durumda olan nakit akış değişkenlerinin, cari oranın bir nedeni olduğu belirlenmiştir. Buna göre;

- İşletmelerin faaliyetlerinden elde ettiği nakit akışları (INA), cari oranın (CR) Granger anlamda bir nedenidir (Prob. $=0,0008$ ).

- İşletmelerin yatırımlarından elde ettiği nakit akışları (YNA), cari oranın (CR) Granger anlamda bir nedenidir (Prob. $=0,0001)$.

- İşletmelerin finansal faaliyetlerinden elde ettiği nakit akışları (FNA), cari oranın (CR) Granger anlamda bir nedenidir (Prob. $=0,0000$ ).

Nakit oran (NR) değişkenine yönelik nedensellik testi sonuçları Tablo 6'te sunulmuştur: 
F. Dereköy 12/4 (2020) 3505-3517

Tablo 6. Nakit Orana Yönelik Panel Nedensellik Testi Sonuçları

\begin{tabular}{|c|c|c|c|c|}
\hline \multirow{2}{*}{$\begin{array}{c}\text { Bağımlı } \\
\text { Değişken }\end{array}$} & $\begin{array}{c}\text { Dişlanan } \\
\text { Değişkenler }\end{array}$ & $\begin{array}{c}\text { Ki-kare } \\
\text { İstatistiği }\end{array}$ & $\begin{array}{c}\text { Serbestlik } \\
\text { Derecesi }\end{array}$ & P Değeri \\
\hline \multirow{2}{*}{$\begin{array}{c}\text { Nakit Oran } \\
\text { (NR) }\end{array}$} & İNA & 1.772787 & 2 & 0.4121 \\
\cline { 2 - 5 } & YNA & 3.376049 & 2 & 0.1849 \\
\cline { 2 - 5 } & FNA & 2.806200 & 2 & 0.2458 \\
\cline { 2 - 5 } & All & 8.516774 & 6 & 0.2026 \\
\hline
\end{tabular}

Tablo 6'dan elde edilen sonuçlara göre, Sonuç (bağımlı) durumunda olan değişken firmaların nakit oranı (NR) olduğunda, nedensel durumda olan nakit akış değişkenlerinin, nakit oranın bir nedeni olmadığı belirlenmiştir. Buna göre;

- İşletmelerin faaliyetlerinden elde ettiği nakit akışları (İNA), nakit oranın (NR) Granger anlamda bir nedeni değildir (Prob. $=0,4121$ ).

- İşletmelerin yatırımlarından elde ettiği nakit akışları (YNA), nakit oranın (NR) Granger anlamda bir nedeni değildir (Prob. $=0,1849$ ).

- İşletmelerin finansal faaliyetlerden elde ettiği nakit akışları (FNA), nakit oranın (NR) Granger anlamda bir nedeni değildir (Prob. $=0,2458$ ).

\section{SONUÇ ve DEĞERLENDİRME}

İşletmelerin finansal durumunu gösteren önemli finansal tablolarından biri olan, nakit akış tablosu, nakit ve nakit benzeri varlıklarda gerçekleşen değişimi açıklamaktadır. Nakit ve nakit benzerleri varlıkların işletmeye girişi ve işletmeden çıkışı olarak tanımlanan nakit akışları (TMS 7), likidite ölçütü olarak ifade edilmektedir. Nakit akışları, nakit akış tablosunda; işletmenin esas faaliyetleri, yatırım ve finansman faaliyetlerine göre sınıflandırılarak raporlanır. Esas faaliyetlere ilişkin nakit akışları, işletmenin hasılat yaratan ana faaliyetleriyle ilgili olup, yatırım faaliyetlerine ilişkin nakit akışları ise, uzun vadeli varlıkların ve nakit benzeri olmayan diğer yatırımların elde edilmesi ve elden çıkarılması sonucunda oluşmaktadır. Bunun yanında, finansman faaliyetlerinden elde edilen nakit akışları, işletmenin ödenmiş sermayesi ve borçlanmalarının büyüklügünde ve kombinasyonunda değişikliklere neden olan nakit girişlerinden ve çıkışlarından elde edilmektedir

Nakit akış tablosu, finansal bilgi kullanıcılarına, işletmeyi pek çok farklı açıdan analiz yapma imkanı sunmaktadır. Özellikle işletmelerin likiditesinin ve borç ödeme yeteneğinin değerlendirilmesine olanak sağlamaktadır (Frank ve James, 2014: 78 ve Şensoy, 2002: 56). Bu bağlamda, çalışmada, likidite ölçütü olarak ifade edilen nakit akışlarının, işletmelerin likidite oranlarını etkileyip etkilemediğinin belirlenmesi amaçlanmıştır.

Çalışmada nakit akışları ile likidite oranları arasında herhangi bir ilişkinin var olup olmadığı, ilişki varsa bu ilişkinin yönü ve düzeyi test edilmiştir. 2014- 2018 yılları arasında Borsa İstanbul KOBİ Sınai Endeks' inde faaliyet gösteren işletmelerin, yıllık finansal verileriyle gerçekleştirilen araştırmada panel veri analizi yöntemi kullanılmıştır. Çalışmada likidite oranlarını temsil eden "cari oran" (CR) ve "nakit oran" (NR) bağımlı değişkenler olarak kullanılmışır. Bağımsız değişkenler olarak ise işletmelerin nakit akışlarını temsil eden, "işletme faaliyetlerinden nakit akışları" (INA), "yatırımlardan nakit akışları" (YNA) ve "finansal faaliyetlerden nakit akışları" (FNA) kullanılmıştır.

Nakit akışları ile likidite oranları arasındaki ilişkinin analizlerle test edilebilmesi için iki model oluşturulmuştur. Ardından modellerin, sabit ya da rassal etkili olarak tahmin edilmesi konusunda Hausman testi yapılarak, model 1 için rassal ve model 2 için ise sabit etkili şekilde tahmin edilmesine karar verilmiştir. Modellerin tahmininden elde edilen sonuçlara göre, işletme faaliyetlerinden, yatırımlardan ve finansal faaliyetlerden elde edilen nakit akışları ile likidite oranları arasında istatistikî olarak anlamlı bir ilişki bulunmamaktadır. Araştırmanın sonucu, literatürde daha önce yapılmış olan çalışmalardan (Sontakke ve Mallya, 2019; Okoye vd., 2016 ve Noor vd., 2012) farklı olarak, nakit akışlarının, cari oran ve nakit oran üzerinde önemli bir etkiye sahip olmadığını ortaya koymaktadır. 
İşletmelerin likidite ölçümünde kullanılan "cari oran" ve "nakit oran", tahakkuk esaslı olarak düzenlenen bilanço verileri kullanılarak hesaplanmaktadır. Bilançoda yer alan finansal veriler gerçekleşmiş, geçmiş faaliyetlerden elde edilmiş olup, işletmenin borç ödeme gücünü anlık olarak göstermektedir. Nakit akışları da işletmenin likiditesini ve borç ödeme becerisini ortaya koyan bir ölçüt olarak tanımlanmaktadır. Ancak nakit akışları, işletmenin belli bir dönem aralığında elde ettiği nakit giriş ve çıkışlarından oluşmakta ve işletmenin nakit pozisyonu yansitmaktadır (Lee, 1993; Lancaster ve Stevens, 1998; Barua ve Saha, 2015; Arnold vd., 2018). $\mathrm{Bu}$ durum, nakit akışları ile likidite oranları arasında bir ilişkinin bulunmamasına dair, araştırma sonucunun nedeni olarak ifade edilebilir.

Çalışmada panel regresyon analizlerinden sonra, çalışma kapsamındaki değişkenlerin durağan olup olmadığını belirlemek için birim kök testleri yapılmış ve ele alınan tüm serilerin bu düzeyde durağan olduğu belirlenmiştir. Bunun sonucunda, nedensellik analizinin yapılmasına karar verilmiştir. Yapılan nedensellik analizinde VEC Granger Causality/Block Exogeneity Wald Testi kullanılmıştır. Panel nedensellik sonuçlarına göre nakit akışlarının iki gecikmeyle, cari oranın bir nedeni olduğu, ancak nakit akış değişkenlerinin, nakit oranın bir nedeni olmadığı tespit edilmiştir. Bu sonuca göre nakit akışlarının, iki dönem sonra (iki gecikme) cari oranın nedeni olabileceği, yani gecikmeli olarak etkileyebileceği söylenebilir. Literatürde ifade edildiği gibi (Kim vd., 2019) işletmeler yeterli düzeyde nakit akışı elde ettiklerinde, vadesi gelen yükümlülüklerini yerine getirebileceklerinden, daha az nakit ve nakit benzeri varlık bulundurmayı tercih edebileceklerdir. Bu durumda, nakit akışı yaratma gücüne sahip olan işletmeler, nakit ve nakit benzeri varlıklar yerine daha fazla ticari alacak ve daha fazla stok bulundurmaya yönlenebilirler.

Araştırma sonuçlarını genel olarak değerlendirdiğimizde, işletmelerin likidite açısından analizinde, bilanço verilerinden elde edilen likidite oranları ile nakit akış tablosundan elde edilen nakit akışları farklı sonuçlar ortaya koymaktadır. Bu nedenle, işletmelerin likidite analizinde, bilanço ve nakit akış tablosu verilerinin beraber değerlendirilmesi, daha doğru sonuçlara ulaşılmasını sağlayacaktır.

Çalışmanın, Borsa İstanbul KOBİ Sanayi Endeksi' nde yer alan ve verilerine ulaşılabilen 40 sanayi işletmesi üzerinde gerçekleştirilmiş olması, daha önce ifade edildiği gibi sonuçların genelleştirilmesi açısından araştırmanın kısıtını oluşturmaktadır. Buna karşın, literatürde nakit akışları ile performans arasındaki ilişki düzeyini belirlemeye yönelik birçok çalışma bulunmasına rağmen nakit akışları ile likidite oranları arasındaki ilişki düzeyini ölçmeye yönelik çok az sayıda çalışmaya rastlanmış olması, literatüre katkı sağlaması açısından çalışmanın önemini ortaya koymaktadır. Bundan sonraki çalışmalar, daha fazla örneklem sayısı ve daha uzun dönemli verilerle gerçekleştirilebilir.

\section{KAYNAKÇA}

Akgüç, Ö. (1998). Finansal Yönetim, İstanbul, Avcıol Basım Yayın.

Arnold, A. G, Ellis, R. B. ve Krishan, V. S. (2018). Toward Effective Use of the Statement of Cash Flows, Journal of Business and Behavioral Sciences, 30 (2), 46- 62.

Ashtiani, A.R. (2005). The Study of Relationship between Accounting Ratios and Operating Cash Flow Measures of Firm Performance and Stock Returns in TSE, Mashad, Islamic Azad University, Iran.

Barua, S. ve Saha, A. K. (2015). Traditional Ratios vs. Cash Flow based Ratios: Which One is Better Performance Indicator?, Advances in Economics and Business, 3 (6), 232- 251.

Bayülken, Y. ve Kütükoğlu, C. (2012). Küçük ve Orta Ölçekli Sanayi İşletmeleri (KOBİ'ler), Ankara, TMMOB Makine Mühendisleri Odası, Yayın No: MMO/583.

Billah, N.M.B, Yakob, N. A., Mc Gowan, C. B. (2015). Liquidity Analysis of Selected Public-Listed Companies in Malasia, International Economics and Business Macrothink Institute, 1 (1), 1- 19.

Bolek, M. ve Grosicki, B. (2012). Liquidity Analysis of Innovative and Traditional Businesses in Poland, Business, Management and Education. 10 (2), 232- 247.

Brush, T.H., Bromiley, P. ve Hendrick, M. (2000). The Free Cash Flow Hypothesis for sales Growth and Firm Performance, Startegic Management Journal, 21, 455- 472. 
Cavlak, H., Cebeci, Y. ve Güneş, N. (2017). Nakit Akış Tablolarının İçerik Analizi Yöntemi ile Değerlendirilmesi, International Journal of Academic Value Studies, 3 (13), 234- 246.

Ceylan, A.ve Karapınar, T. (2008). İşletmelerde Finansal Yönetim, Bursa, Ekin Basım Yayın Dağıtım.

Chikashi, T. O. (2013). An Investigation of Comprehensive Income and Firm Performance: The Case of The Electric Appliances Industry of Tokyo Stock Exchange, Journal of Accounting and Finance Research, 2 (2), 29- 35.

Cyril, U.M., Lawretta, C.I. ve Adakole, E.E. (2016). Effect of Cash Flow Statementon Performanceof Selected Food Beverage Companies in Nigeria, Idors Journal of Current Issues in Social Sciences, 2 (1), 47- 54.

Frank, B.P. ve James, O.K. (2014). Cashflow and Corporate Performance: a Study of Selected food and Beverages Companies in Nigeria, Europian Journal of Accounting and Finance Reserach, 2 (7), 77- 87.

Gökçen, G., Ataman, B. ve Çakıcı, C. (2011). Türkiye Finansal Raporlama Standartları Uygulamaları, İstanbul, Türkmen Kitapevi.

Göktaş, P., Pekmezci, A. ve Bozkurt, K. (2019). Ekonometrik Serilerde Uzun Dönem Eşbütünleşme ve Kısa Dönem Nedensellik, Güncellenmiş 2. Bask1., Ankara, Gazi Kitabevi.

Greene, W.H. (2003). Econometric Analysis, 5th ed., New Delhi, Pearson Education Publishers.

Gup, B. E., Samson W. D., Dugan M. T., Kim M. J. ve Jittrapanun, T. (1993). An Analysis of Patterns from the Statement of Cash Flows, Financial Practice and Education, Fall, 73-79.

Günay, S.G. (2014). İşletme Finansının Temelleri, Edirne, Paradigma Akademi Yayınları.

Günceme, Ü. ve Arsoy, A.P. (2006). Muhasebe Standartlarındaki Sınıflandırılmış Nakit Akım Tablosu Formatı ile Finansal Performansın Ölçülmesi, Muhasebe Finansman Dergisi, 30, 66- 74.

Güriş, S. (2015). Stata ile Panel Veri Modelleri, İstanbul, Der Yayınları, 454.

Karapınar, A. ve Eflatun, A.O. (2017). Büyük ve Orta Boy İşletmeler için Finansal Raporlama Standardı Uygulama ve Yorumlar 2018 BOBI FRS, Ankara, Gazi Kitapevi Tic. Ltd. Sti.

Karapınar, A. ve Zaif, F.A. (2013). Finansal Analiz, Ankara, Gazi Kitapevi.

Karğın, M. ve Aktaş, R. (2011). Türkiye Muhasebe Standartlarına Göre Raporlanmış Nakit Akış Tablosu ve Analizi, Muhasebe ve Finansman Dergisi, 52, Ekim 2011, 1- 24.

Kim, C., Mauer, D.C. ve Sherman, A.E. (1998). The Determinants of Corporate Liquidity: Theory and Evidence, The Journal Financial and Quantitative Analysis, Cambridge University Press, 33 (3) (Sep. 1998), 335- 359.

Lancaster, C., Stevens, J.L. (1998). Corporate Liquidity and The Significance of Earnings Versus Cash Flows, Journal of Applied Business Research, 14 (4), 27- 38.

Lazol, İ. (2008). Mali Analiz Uygulamaları, Bursa, Ekin Basım Yayın Dağıtım.

Lee, T.A. (1993). Cash Flow Reporting: A Recent History of an Accounting Practice, New York, Garland Publishing,

Noor, M.I., Nour, A., Musa, S. ve Zordan, S. (2012). The Role of Cash Flow in Explaining The Change in Company Liquidity, Journal of Advanced Social Research, 2 (4), June 2012, 231- 243.

Ogbeide, S. ve Akanji, B. (2017). A Study on The Relationship between Cash-Flow and Financial Performanceof Insurance Companies: Evidence from a Developing Economy, Review of International Comparative Management", 18 (2), May 2017, 148-157.

Okka, O. (2006). Finansal Yönetime Giriş, Ankara, Nobel Yayın Dağıtım.

Okoye, P-V.C., Nestor, A, Nwezw, C.L. ve Obi, J.C. (2016). Cash Flow Statement and Liquidity: Empirical Evidence from Quated Banks in Nigeria, Proceeding of Faculty of Management Sciences' 2016 International Conference 8th-10th November, Nigeria, 705- 718. 
Omag, A. (2016). Cash Flows from Financing Activities. Evidence from the Automotive Industry, International Journal of Academic Research in Accounting, Finance and Management Sciences, 6 (1), January 2016, 115122.

Özdemir, S., Ersöz, H. ve Sarığlu H. (2007). Küçük Girişimciliğin Artan Önemi ve KOBİ'lerin Türkiye Ekonomisindeki Yeri, Sosyal Siyaset Konferanslarn Dergisi, Sayı 53, 173- 230.

Özerhan, Y. ve Yanık, S. (2012). Türkiye Muhasebe Standartları Türkiye Finansal Raporlama Standartları, Ankara, TÜRMOB Yayınları- 427.

Petro, F. ve Gean F. (2014). A Logical Approach to The Statement of Cash Flows, American Journal of Business Education, 7 (4), 315- 324.

Robinson, T. R., Munter, P. ve Grant, J. (2004). Financial Statement Analysis, New Jersey, Pearson Prentice Hall.

Sarıkovanlık, V., Koy, A., Akkaya, M., Yıldırım, H.H. ve Kantar, L.K. (2019). Finans Biliminde Ekonometri Uygulamaları, 1. Baskı, Ankara, Seçkin Yayıncılık.

Sontakke, K.A. ve Mallya, D. (2019). Study of Correlation between Liquidity Ratios and Cash Flow Statement, International Journal of Money, Banking and Finance, 8 (1), January- June 2019, 30- 31.

Subatnieks, K. (2005). Concept of Cash Flow and Assesment of Cashflow Ratios of Latvian Companies, Organizacijo Vadyba: Sisteminia Tyrimai, 36, 163-176.

Şensoy, N. (2002). Nakit Akış Tabloları, İstanbul, Yaylım Yayıncılık.

Tatoğlu, F.Y. (2012). İleri Panel Veri Analizi, İstanbul, Beta Yayıncılık.

Tokaç, A. (2005). Finansal Raporları Okuma Metodları, İstanbul, Beta Basım A.Ş.

Uygurtürk, H. ve Vargün, H. (2018). Nakit Akışı ile Karlılık Arasındaki İlişki: Taşıt Araçları Sektörü Üzerine Bir Araştırma, Muhasebe Bilim Dünyası Dergisi, 20 (3), Eylül 2018, 705- 727.

Watson. J. (2005). The Association of Various Earnings and Cash Flow Measures of Firm Performance and Stock Returns, School of Accounting, University of Technology, Sydney.

Williams, J.R., Haka, S.F., Bettner, M.S. ve Carcello, J.V. (2008). Financial and Managerial Accounting, New York, McGraw-Hill Irwin.

Wolk, H.I. ve Tearney, M.G. (1997). Accounting Theory, Cincinati, Ohio, South-Western College Publishing.

Yero, J.I. ve Usman, S.H. (2013). Free Cash Flow, Growth Opportunity and Performance of Nigerian Quoted Food, Tobacco and Beverages Firms, Conference Paper, March 2013.

Yılmaz, M.K. ve İçten, O. (2018). Borsa İstanbul'da İşlem Gören Gayrimenkul Yatırım Ortaklarının Nakit Akım Odaklı Finansal Performans Analizi, Finans Politik ve Ekonomik Yorumlar, 55 (635), 73- 87.

Zhou, H., Yang, S. and Zhang, M. (2012). Relationship between Free Cash Flow and Financial Performance Evidence from the Listed Real Estate Companies in China, 2012 International Conference on Innovation and Information Management, IPCSIT, 36, 331- 33.

TMS 7 “Nakit Akış Tablosu” Standardı 18/01/2005 Tarih ve 25704 Sayılı Resmi Gazete

Borsa İstanbul, http://www.borsaistanbul.com/veriler/verileralt/mali-tablolar-arsiv (Erişim Tarihi: 29 Kasım 2019).

Kamuyu Aydınlatma Platformu, http://www.kap.org.tr/Endeksler (Erişim Tarihi: 29 Kasım 2019). 